\title{
BLOOD PRESSURE CONTROL IN HYPERTENSIVE PATIENTS WITH TYPE 2 DIABETES MELLITUS
}

\author{
Irina Pârvu ${ }^{1,2}$, Ioana Verde ${ }^{1}$, Camelia Nicolae ${ }^{1,2}$, Adriana Iliesiu ${ }^{1,2}$ \\ ${ }^{1 " C a r o l ~ D a v i l a " ~ U n i v e r s i t y ~ o f ~ M e d i c i n e ~ a n d ~ P h a r m a c y, ~ B u c h a r e s t, ~ R o m a n i a ; ~}$ \\ "2Prof. Dr. Th. Burghele" Clinical Hospital, Bucharest, Romania. \\ Corresponding author: \\ Irina Pârvu, 20 Panduri Rd, District 5, Bucharest, Romania: \\ E-mail: irina.parvu@drd.umfcd.ro
}

\begin{abstract}
Introduction and objective. Blood pressure (BP) goals and glycemic targets are only reached in $40 \%$ and $50 \%$ of patients, respectively. The objective of this observational retrospective cohort study was analyzing BP control with antihypertensive therapy in patients with diabetes mellitus (DM) and arterial hypertension (HTN) in clinical practice.

Methods. 156 hospitalized hypertensive patients with type 2 DM were divided into 2 groups (G): G1 - uncomplicated and G2 - complicated DM, with micro- and macrovascular involvement, followed retrospectively for 2 years. BP control with antihypertensives was analyzed with respect to DM control, complications, hospital readmissions for cardiovascular disease and allcause mortality.
\end{abstract}

Results. Of the 156 patients, 71 (45.6\%) males, mean age $66.7 \pm 9.8$ years, 94 (60.3\%) were included in G2. Ninety-one patients (58.3\%) were rehospitalized, G2 patients having a significantly higher risk of readmission $(p=0.006)$. BP was controlled in $57.7 \%$ patients at first, and in 59.3\% patients on the last hospitalization, while DM was initially controlled in $49.3 \%$ patients, and in $54.9 \%$ on the last readmission.

The number of antihypertensive drug classes was significantly higher in G2 (3.5 vs 3.1, $p=0.03)$. Fifteen (9.6\%) patients were initially on fixed-dose combinations (FDC). All-cause mortality after 2 years was $12.2 \%$, strongly associated with DM complications $(p=0.005)$, with a protective effect from controlled DM $(p=0.045)$.

Conclusion. More than forty percent of the patients had uncontrolled long term HTN with frequent re-hospitalizations and increased mortality. Better BP control could be achieved by changing therapy, notably by FDC, promoting patient adherence.

Keywords: arterial hypertension, diabetes mellitus, control, complications. 


\section{INTERNAL}

\section{Original Papers}

\section{Rezumat}

Introducere şi obiectiv. Tintele de tensiune arterială (TA) şi glicemice sunt atinse doar la 40\%, respectiv 50\% dintre pacienţi. Obiectivul acestui studiu observaţional retrospectiv de cohortă a fost analiza controlului TA sub terapie antihipertensivă la pacienţii cu diabet zaharat (DZ) şi hipertensiune arterială (HTA) in practica clinică.

Metodă. 156 hipertensivi spitalizaţi cu DZ tip 2 au fost impărţiti în 2 grupuri (G): G1 - DZ necomplicat şi G2 - DZ complicat, cu afectare micro- şi macrovasculară, urmăriţi retrospectiv 2 ani. Controlul TA sub antihipertensive a fost analizat relativ la controlul şi complicaţiile DZ, respitalizările pentru boli cardiovasculare şi mortalitatea de orice cauză.

Rezultate. Din 156 de pacienţi, 71 (45,6\%) bărbaţi, cu vârsta medie $66.7 \pm 9.8$ ani, 94 (60,3\%) erau în G2. 91 (58,3\%) au fost respitalizaţi, G2 având un risc semnificativ crescut de reinternare ( $p=0,006)$. Controlul TA a fost obţinut initial la 57,7\% bolnavi, iar la ultima respitalizare la 59,3\%, DZ fiind iniţial controlat la 49,3\%, iar la ultima reinternare la 54,9\%.

Numărul claselor de medicație antihipertensivă a fost semnificativ mai mare în G2 (3.5 vs 3.1 clase, $p=0,037)$. Cinciprezece $(9,6 \%)$ bolnavi erau iniţial cu combinaţii în doză fixă (CDF). Mortalitatea de orice cauză la 2 ani a fost 12,2\%, asociată complicaţiilor $D Z$ ( $p=0,0054)$, cu efect protector al DZ controlat $(p=0,045)$.

Concluzii. Peste patruzeci la sută dintre pacienţi aveau HTA necontrolată pe termen lung, $c u$ reinternări frecvente şi mortalitate crescută. Un control optimizat al TA s-ar realiza prin modificarea terapiei, prin CDF, promovând aderenţa la tratament.

Cuvinte-cheie: hipertensiune arterială, diabet zaharat, control, complicaţii.

\section{Introduction}

Cardiovascular (CV) risk in patients with type 2 diabetes mellitus (DM) and arterial hypertension (HTN) is $75 \%$ greater than in diabetics without HTN, and this has been documented by numerous studies so far, while the prevalence of HTN in diabetics is high $^{(1-3)}$. Apart from the frequent association of HTN and DM, suggesting possible common genetic and/or pathophysiological pathways, there is also a bidirectional impact, as both conditions tend to aggravate each other, with similar risk factors and target organs (brain, kidneys, heart, eyes, blood vessels) ${ }^{(4)}$.

Antihypertensive therapy therefore becomes paramount, in order to control CV risk and the decline of renal function. Treatment is mainly 
based on blockade of the renin-angiotensinaldosterone system (RAAS) including angiotensin-converting enzyme inhibitors (ACEI), angiotensin receptor blockers (ARBs), calcium channel blockers (CCB) and diuretics, with individualized therapeutic targets ${ }^{(5)}$. Fixed-dose combinations (FDC) of two or three drugs are strongly recommended by current Guidelines for optimizing patient adherence ${ }^{(5)}$. Control seems to be partially lacking, as only $40 \%$ of everyday life patients achieve BP goals, as proven by a very recent analysis of records from 2590 patients in 4 randomized controlled-trials ${ }^{(6)}$. Regarding DM control, glycemic targets are only reached in about $50 \%$ of patients, as suggested by a review of data from the National Health and Nutrition Examination Survey (NHANES), as low as 30$40 \%$ in commercial insurance systems and Medicaid, while improvement in the past decade fails to show ${ }^{(7)}$.

\section{Objective}

The objective of this observational retrospective cohort study was the analysis of $\mathrm{BP}$ control under antihypertensive treatment in diabetic patients with HTN, at very high CV risk, in everyday clinical practice, with respect to DM complications, DM control, rehospitalizations for $\mathrm{CV}$ disease and allcause mortality.

\section{Study population and method}

The study population included 157 consecutive patients admitted to the Cardiology Department of a clinical hospital, whose discharge diagnosis included both HTN and type 2 DM, irrespective of DM complication status, while excluding type 1 DM patients and rehospitalizations of the same patient during the established interval.
One patient had no documentation of DM complications, nor clinical parameters mentioned in the discharge summary and was excluded from analysis. The remaining 156 patients were followed retrospectively for 2 years after the initial discharge from the hospital. The patients were divided into two groups (G): G1 - patients with uncomplicated DM and G2 - patients with DM and micro- and macrovascular diabetic complication.

Study variables included demographical data, the recommended antihypertensive therapy, clinical data (including systolic and diastolic blood pressure, documented DM complications, reasons for admission and comorbidities), fasting plasma glucose and glycosylated hemoglobin ( $\mathrm{HbAlc}$ ), rehospitalizations in the Cardiology Department during the following 2 years, and vital status after 2 years. Statistical analysis was performed using Microsoft Excel version 2013 and Epi Info version 7.2.2.2. Numerical variables are expressed as mean \pm standard deviation (SD), and categorical variables are expressed as absolute value and percentage. Comparison was performed by using nonparametric tests (for quantitative data), and Chi squared and Fisher Exact test (for qualitative data), and the null hypothesis was rejected when two-tailed p-value<0.05. Access to the hospital computer system and storage of data was provided by the local computers of the hospital. Access to the database was secured, password-protected, and all the ethical and integrity requirements were met.

\section{Results}

\section{Initial hospitalization}

Patients with both HTN and type 2 DM represented approximately $13.5 \%$ of all Cardiology department discharges during the 


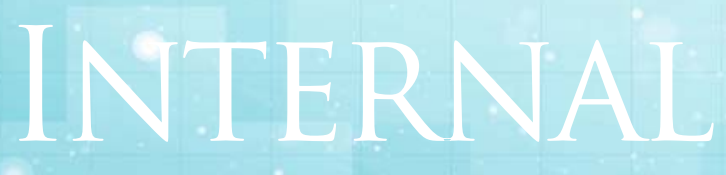

Original Papers

target time period. The 156 patients in the study population had a mean age of $66.7 \pm 9.8$ years, $71(45.6 \%)$ of patients were male. Sixty-two patients, $39.7 \%$, were included in $\mathrm{G} 1$, and 94 patients, $60.3 \%$, in G2. The characteristics of the 2 study groups on the first admission, as well as the statistical significance of intergroup differences are shown in Table 1. Patients in G1 were marginally younger, with a mean age of 65.5 years, while in $G 2$ it was 67.5 years $(p=0.21)$, with a slight non-significant male prevalence in G1 $(51.6 \%)$, versus G2, where men accounted for only $43.6 \%$ of patients ( $p$ $=0.26$ ) .

The reasons for admission on the Cardiology Department were mainly represented by heart failure (58 patients, 37\%), ischemic heart disease (46 patients, 30\%), high BP (20 patients, 13\%), arrhythmias (11 patients, $7 \%$ ), and other diseases (pulmonary embolism, deep vein thrombosis, peripheral artery disease) (21 patients, 13\%), as shown in Figure 1.

\section{Diabetes mellitus}

During the first admission, the glycemic parameters were within the recommended targets in 77 (49.3\%) of patients, based on blood glucose and Alc hemoglobin.

Ninety-nine patients (63.8\%) had diabetic nephropathy, and 93 patients (59.5\%) had diabetic neuropathy, by far the most common complications. In G2, the mean number of complications per each patient was $1.8 \pm$ 1.22 (Figure 2). The presence of DM complications was significantly associated with the number of years of DM evolution, with a $\mathrm{p}$-value approaching 0 .

Hypertension control on the first admission was achieved in 90 patients (57.7\%), 54.8\% in G1 and $58.5 \%$ in $\mathrm{G} 2$. In regard to antihypertensive therapy on the first admission, all patients received antihypertensive therapy according to guidelines, including ACEI (64.3\%), ARB $(39.7 \%)$, CCB $(45.8 \%)$, BB $(84 \%)$, diuretics (74.9\%) and other drugs (14.2\%). The total number of antihypertensive drug classes was significantly higher G2 compared with in G1 (3.5 classes vs 3.1 classes respectively, p $=0.037$ ).

Patients with diabetic nephropathy had a significantly higher number of antihypertensive drug classes (on average, 3.8 versus 3.3 classes, $p=0.023)$. Only 15 patients $(9.6 \%)$ were on FDC on the first admission, without difference between the 2 groups ( $p=0.58$ ). Patients with HTN not reaching BP targets on the initial evaluation were significantly younger $(64.2 \pm 10.7$ years versus $68.5 \pm 8.7$ years, $p$ $=0.002)$, more obese $(71.2 \%$ versus $52.2 \%, p$ $=0.016$ ), and with slightly more comorbidities than the ones with controlled HTN. Mean BP was $152.5 / 87.4 \mathrm{mmHg}$ in patients with partially 


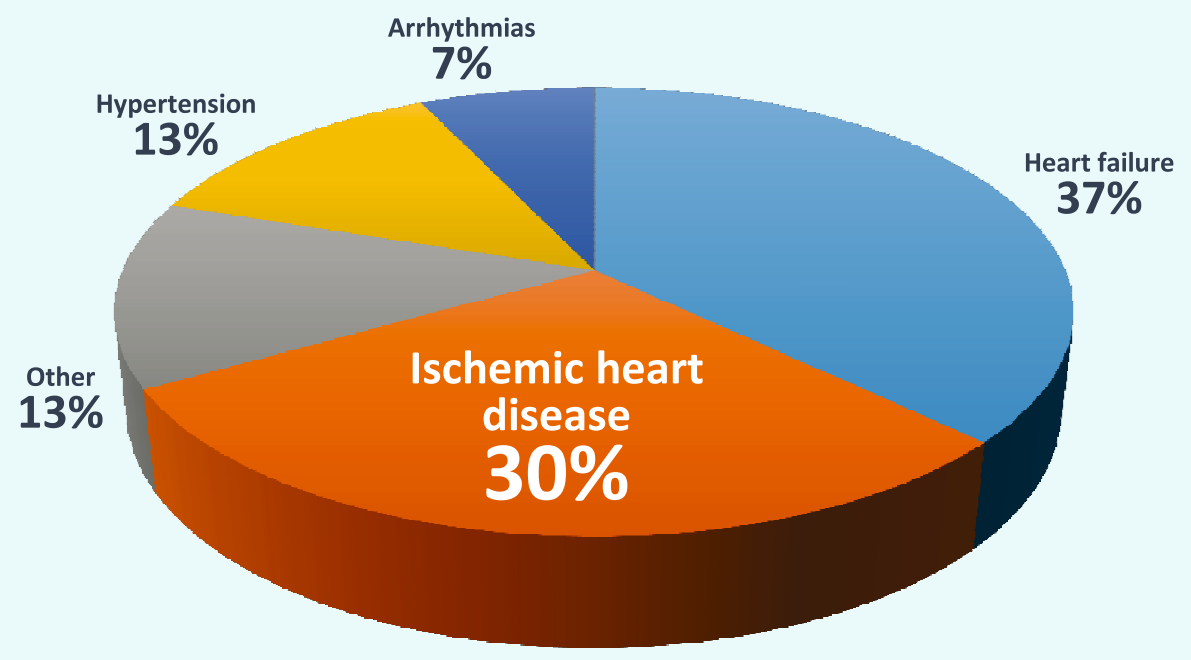

Figure 1. Reasons for Cardiology admission in the study group

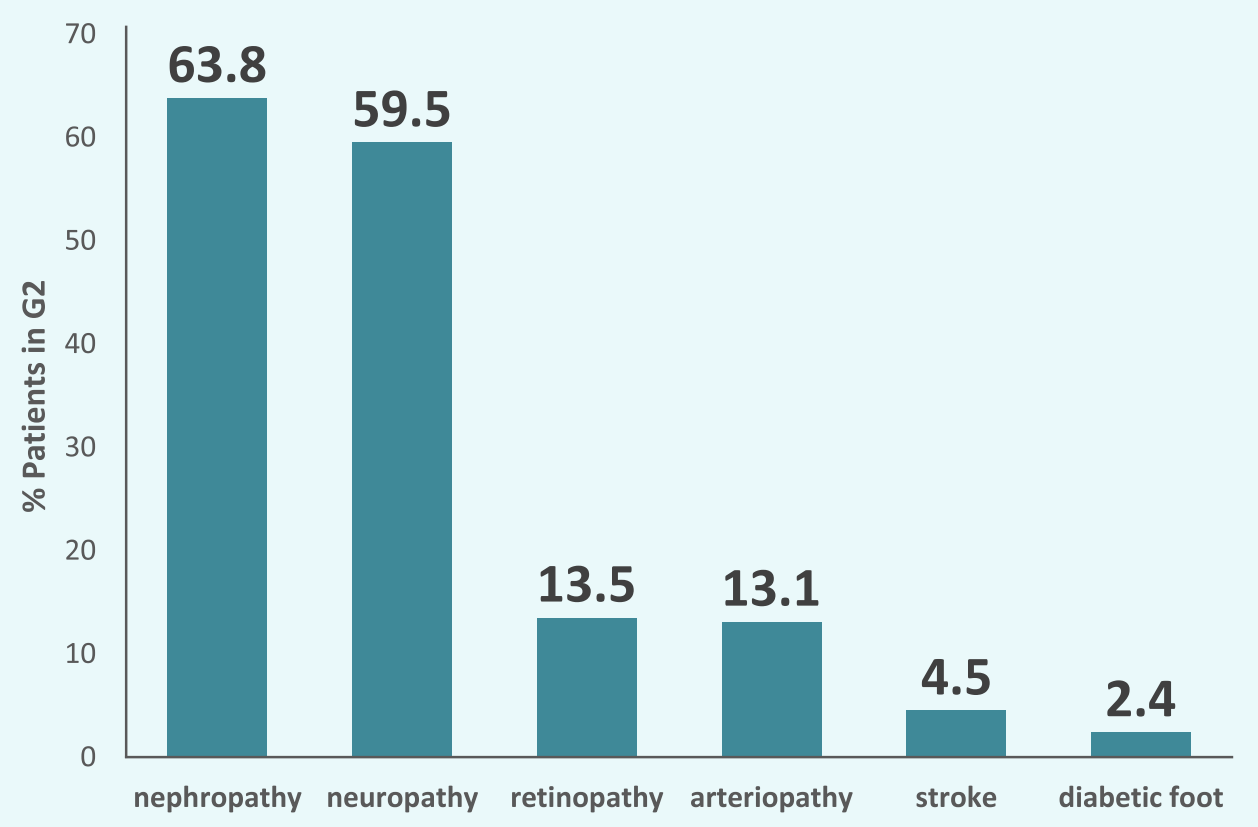

Figure 2. Diabetes mellitus complications in group G2 


\section{INTERNAI}

\section{Original Papers}

controlled BP, and $131.1 / 78.1 \mathrm{mmHg}$ in those with BP within target (see table 2).

\section{Hospital readmissions}

A total of 91 (58.3\%) patients were readmitted, mostly for heart failure decompensation (57 patients, 62.7\%), arrhythmias (29 patients, $31.6 \%$ ) or ischemic heart disease (21 patients, $23.07 \%)$. The last hospital readmission occurred after an average of 16.2 months from the first admission. The mean number of readmissions/patient was 1.52. G2 patients had a higher risk for patients to be rehospitalized in the Intensive Care Unit (29 patients over 2 years, $18.5 \%$ of the initial study population, $p=0.006$ ).

$\mathrm{BP}$ on the last admission was controlled in 54 (59.3\%) of patients out of the 91 rehospitalized patients, $46.9 \%$ in $\mathrm{G} 1$ and $46.7 \%$ in G2. Mean BP was $152.5 / 87.4 \mathrm{mmHg}$ in patients with partially controlled BP, and 131.1/78.1 $\mathrm{mmHg}$ in those with BP within target (see Table 2). HTN treatment was then changed in 29 $(31.8 \%)$ of the readmitted patients. Only 5 $(5.49 \%)$ of all readmitted patients with treatment changes were prescribed FDC. The DM was controlled in 50 (54.9\%) of patients. Figure 3 shows a comparative view of therapeutic control of HTN and DM on the first and on the last admissions. The comparative mean values of blood pressure and glycemic parameters on study groups, on the first admission and on the last readmission in the
91 rehospitalized patients are shown in table 2 . The number of BP-lowering drug classes the patients received was significantly associated with the number of rehospitalizations ( $p$ $=0.021$ ). Readmitted patients had 3.6 classes on average versus 3.1 classes of antihypertensive drugs in patients who were not rehospitalized during the next 2 years ( $p$ $=0.012$ ).

\section{Mortality}

All-cause mortality after 2 years was 12.2\% (19 patients, 17 from G2). All-cause mortality was strongly associated with the presence of DM complications ( $p=0.005$, odds ratio, OR $=1.18$, 95\% confidence interval 1.05;1.31), and with significant longer duration of hospital stay at the first hospitalization in G2 patients (4.99 days in survivors versus 9.84 days in deceased patients, $p=0.0002$ ). Complicated DM and diabetic nephropathy $(p=0.0005$, $\mathrm{OR}=1.22$, 95\% confidence interval 1.06;1.41) proved to be possible predictors for mortality in patients with known CV disease, with a protective effect from controlled DM ( $p=0.045$, $\mathrm{OR}=0.89,95 \%$ confidence interval $0.74 ; 0.98$ ), as shown in the diagram in Figure 4.

\section{Discussion}

In the present study, the most prevalent reasons for hospitalization in Cardiology Department for patients with DM and HTN 


\begin{tabular}{|c|c|c|c|}
\hline Parameter & G1 (N=62) & $\mathbf{G} 2(\mathrm{~N}=94)$ & p-value \\
\hline \multicolumn{4}{|l|}{ Clinical characteristics } \\
\hline Age (years) & $65.5 \pm 8.3$ & $67.5 \pm 7.6$ & 0.21 \\
\hline Male sex $(\%)$ & $32(51.6 \%)$ & $40(42.5 \%)$ & 0.26 \\
\hline Blood pressure $(\mathrm{mmHg})$ & $145.7 / 84.2$ & $147.5 / 84$ & 0.94 \\
\hline Heart rate (beats/minute) & $79.4 \pm 7.3$ & $91.3 \pm 8.2$ & 0.89 \\
\hline \multicolumn{4}{|c|}{ Risk factors and cardiovascular disease } \\
\hline Obesity & $35(56.5 \%)$ & $57(60.6 \%)$ & 0.68 \\
\hline Smoking & $18(29 \%)$ & $22(23.4 \%)$ & 0.39 \\
\hline Alcohol consumption & $4(6.5 \%)$ & $7(7.4 \%)$ & 0.55 \\
\hline Ischemic heart disease & $46(74.2 \%)$ & $85(90.4 \%)$ & 0.006 \\
\hline Prior myocardial infarction & $4(6.5 \%)$ & $21(22.3 \%)$ & 0.008 \\
\hline Arrhythmias, mainly atrial fibrillation & $16(25.8 \%)$ & $34(36.2 \%)$ & 0.03 \\
\hline Heart failure & $30(48.4 \%)$ & $68(72.3 \%)$ & 0.016 \\
\hline \multicolumn{4}{|l|}{ Comorbidities } \\
\hline Lung disease & $15(24.2 \%)$ & $23(24.5 \%)$ & 0.96 \\
\hline Kidney disease & $23(37.1 \%)$ & $56(59.6 \%)$ & 0.005 \\
\hline Liver disease & $20(32.3 \%)$ & $15(16 \%)$ & 0.016 \\
\hline Gastrointestinal disease & $14(22.6 \%)$ & $17(18.1 \%)$ & 0.49 \\
\hline Thyroid disease & $2(3.2 \%)$ & $10(10.6 \%)$ & 0.12 \\
\hline Cancer & $4(6.5 \%)$ & $5(5.3 \%)$ & 0.74 \\
\hline
\end{tabular}

Table 1. Characteristics, risk factors and comorbidities in the 2 study groups, on the initial hospital admission. $G=$ group

\begin{tabular}{|l|l|l|l|l|l|}
\hline & $\begin{array}{l}\text { Mean BP } \\
\mathbf{G 1 + G 2} \\
(\mathbf{m m H g})\end{array}$ & $\begin{array}{l}\text { Mean BP } \\
\text { (uncontroll } \\
\text { ed) } \\
(\mathbf{m m H g})\end{array}$ & $\begin{array}{l}\text { Mean BP } \\
\text { (controlled) } \\
(\mathbf{m m H g})\end{array}$ & $\begin{array}{l}\text { Mean FPG } \\
\mathbf{G} 1+\mathbf{G 2} \\
(\mathbf{m g} / \mathbf{d L})\end{array}$ & $\begin{array}{l}\text { Mean HbA1c } \\
\mathbf{G 1 + G 2} \\
(\%)\end{array}$ \\
\hline $\begin{array}{l}\text { Initial } \\
\text { admission }\end{array}$ & $146.8 / 84.1$ & $167 / 85.6$ & $127.9 / 82.1$ & $156.7 \pm 57.9$ & $7.5 \pm 1.6$ \\
\hline $\begin{array}{l}\text { Last } \\
\text { admission }\end{array}$ & $142.5 / 83.2$ & $152.5 / 87.4$ & $131.1 / 78.1$ & $140.7 \pm 44.9$ & $7.2 \pm 1.8$ \\
\hline
\end{tabular}

Table 2. The mean values of blood pressure and glycemic parameters on the first admission and on the last readmission, in the 91 rehospitalized patients.

$G=$ group, $F P G=$ fasting plasma glucose, $H b A 1 c=$ glycosylated hemoglobin 


\section{INTER}

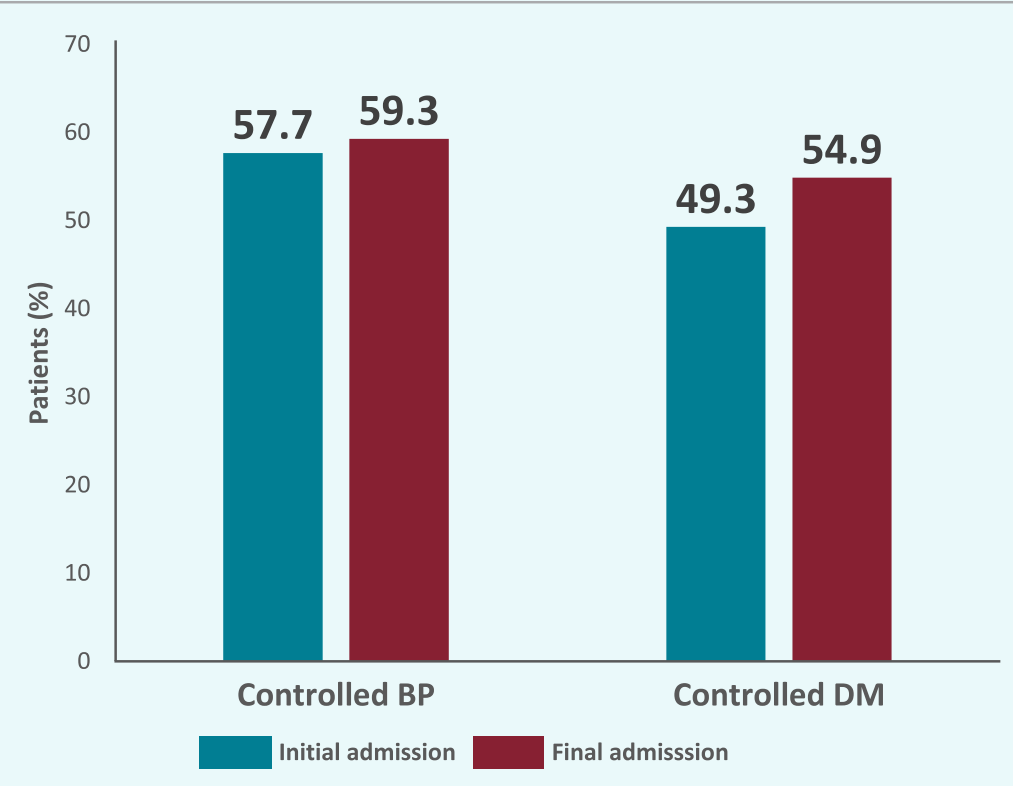

Figure 3. Blood pressure and diabetes mellitus control on the first and last hospitalization $D M=$ diabetes mellitus, $B P=$ blood pressure

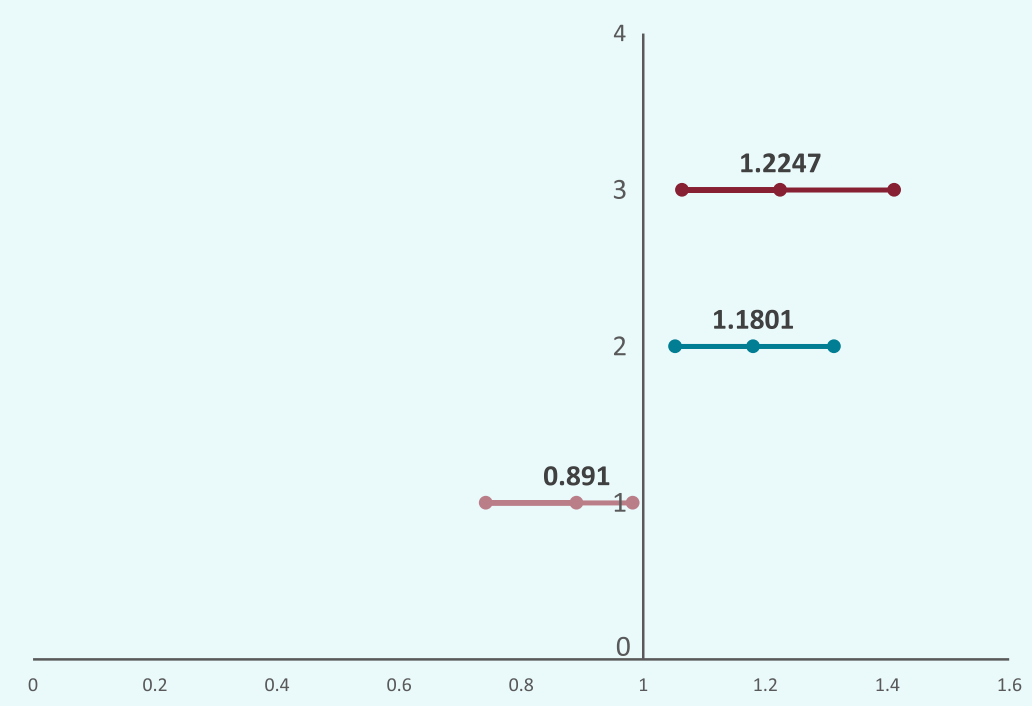

Figure 4. Risk factors associated with all-cause mortality in the study population $D M=$ diabetes mellitus 
were heart failure, ischemic heart disease and arrhythmias such as atrial fibrillation, comparable with literature data where heart failure and ischemic heart disease are the most prevalent conditions for hospital admissions ${ }^{(8,9)}$.

Most diabetic and hypertensive patients at very high risk included in the present study have documented complications of DM, largely represented by neuropathy and nephropathy, in approximately two third of patients with complicated DM. These findings are consistent with literature data, as HTN is a documented high-risk factor for both microand macrovascular complications of DM. The management of HTN, a major risk factor for atherosclerosis, and a promoter of progression of renal damage, by glomerular hyperfiltration, diminishes the vascular risk in $\mathrm{DM}^{(10)}$.

Diabetic nephropathy generated a reduced glomerular filtration rate in $59 \%$ patients of the present study, leading to higher BP levels, and therefore these patients required complex antihypertensive therapy with more than three drug classes in order to control BP. The number of drug classes to control BP proved to be a predictor for rehospitalizations, reflecting patients with more difficult to treat HTN, with more comorbidities, both CV and non-CV. Literature data indicates that around two thirds of patients with DM and HTN will require two or more different antihypertensive drugs to reach the new target blood pressure recommended by guidelines ${ }^{(11)}$.

Hospital readmissions for CV causes, mostly heart failure, arrhythmias, and ischemic heart disease, occurred in almost $60 \%$ of the study group. The presence of DM complications accounted for a higher risk for patients to be re-hospitalized. The number of antihypertensive classes for HTN control, reflecting the burden of more severe and difficult to treat HTN and more comorbid conditions, was in close relation with the readmission of these patients.

All-cause mortality was significantly higher in patients with complicated DM, while DM control offered some protection. Our results are similar to the literature data confirming the bidirectional impact of HTN and DM that could worsen the prognosis of each condition, as well as comorbidities. In a study from 2011, with a follow-up of 4154 person-years concerning the Framingham cohort, exploring the excess risk of $\mathrm{CV}$ events in diabetic individuals attributable to HTN, the population-attributable risk from HTN was $30 \%$ for all-cause death ${ }^{(3)}$.

In the present study, the hypertensive patients with DM were treated according to the current guidelines at the time, for the most part. The DM control was around 50\%, with a slight better control on re-admission. In terms of control of BP control, the efficacy of the treatment for HTN on both the first, and the last hospitalization was only just less than $60 \%$, same as recent data large trials and registers ${ }^{(6,7)}$.

Thus, despite substantial progress in antihypertensive therapy during the past decade, the results tend to stay around the same level of control. The reason for lack of HTN control in patients with DM in our study is multifactorial, although the efficacy of the antihypertensive drugs is not the cause, because in randomized control trials most of the HTN patients $(90-95 \%)$ do not have resistance to treatment ${ }^{(5)}$. In this study, only one third of treatment schedules were modified, mostly by changing dosage, showing persistence in maintaining therapy despite suboptimal BP control.

The failure to adapt the drug doses or to change antihypertensive treatment due to physician inertia is a well-known factor for 


\section{INTERNAL}

\section{Original Papers}

incomplete BP control $^{(12)}$. Another reason could be patient resistance to change a certain drug $^{(13)}$.

The complexity of treatment, for HTN and also for DM and other CV and non-CV diseases, leading to polypharmacy, is another factor contributing to increase the probability of patient non-adherence. It has been documented that $40 \%$ of patients with three pills where non-adherent to treatment, while patients receiving five or more pills had a very high rates of non-adherence ${ }^{(14)}$. European HTN guidelines underline the importance of a single pill combination for HTN treatment ${ }^{(5)}$. However, FDC prescription in our study was very low, under $10 \%$ on first admission, with an additional $5.5 \%$ of patients on readmission.

Thus, the treatment strategy to improve BP control to the recommended lower BP targets, especially in this very high-risk HTN patients with DM, should include the combination of antihypertensive drugs from different classes at optimal doses, the addition of a new class of antihypertensive drugs and, notably, the use of FDC to increase patient adherence.

Limits of the current research include the retrospective analysis of patients, as the study only included patients admitted to the hospital, not hypertensive diabetics from the general population. The lack of complete information recorded in electronic medical documents, also limit the accessible information. Also, assessing adherence to therapy was not possible retrospectively.

\section{Conclusions}

More than forty percent of the patients with diabetes mellitus and arterial hypertension included in the present study had inadequate blood pressure control and around fifty percent had insufficient glycemic control, which has been associated with rehospitalization and increased mortality. Hypertensive and diabetic patients, in particular with complicated diabetes, require a higher number of antihypertensive drugs, while fixed dose combinations were recommended to a very small proportion of patients.

In order to reach the blood pressure targets recommended by the guidelines, antihypertensive therapy should be started as early as possible. Also, a better blood pressure control could be achieved by customizing the treatment and by routine use of fixed dose combinations, boosting patient adherence to therapy.

Conflicts of interest: none.

Financial support: none. 


\section{References}

1. Hypertension in Diabetes Study (HDS): I. Prevalence of hypertension in newly presenting type 2 diabetic patients and the association with risk factors for cardiovascular and diabetic complications. J Hypertens 1993;11:309-317.

2. Govindarajan G, Sowers JR, Stump CS. Hypertension And Diabetes Mellitus. European Cardiovascular Disease 2006;2(1):1-7.

3. Chen G, McAlister FA, Walker RL, şi colab. Cardiovascular outcomes in framingham participants with diabetes: the importance of blood pressure. Hypertension 2011 May;57(5):891-7. doi: 10.1161/ HYPERTENSIONAHA.110.162446.

4. Powers AC. Diabetes Mellitus: Complications. In: Kasper D, Fauci A, Hauser S, Longo D, Jameson JL, Loscalzo J, ed. Harrison's Principles of Internal Medicine. $19^{\text {th }}$ ed. New York: The McGraw-Hill Companies, Inc.; 2015;419: 2422-2430. ISBN-13: 978-0071802154.

5. Williams B, Mancia G, Spiering W, şi colab. 2018 ESC/ESH Guidelines for the management of arterial hypertension. Eur HeartJ 2018 Sep 1;39(33):3021-3104. doi: 10.1093/eurheartj/ehy339. Erratum in: Eur Heart J 2019 Feb 1;40(5):475.

6. Bryant $K B$, Sheppard JP, Ruiz-Negrón $N$, şi colab. Impact of Self-Monitoring of Blood Pressure on Processes of Hypertension Care and Long-Term Blood Pressure Control. J Am Heart Assoc 2020 Aug 4;9(15):e016174. doi: 10.1161/JAHA.120.016174.

7. Edelman SV, Polonsky WH. Type 2 Diabetes in the Real World: The Elusive Nature of Glycemic Control. Diabetes Care 2017 Nov;40(11):1425-1432. doi: 10.2337/dc16-1974.

8. Wu YM, Liu CC, Yeh CC, şi colab. Hospitalization outcome of heart diseases between patients who received medical care by cardiologists and noncardiologist physicians: A propensity-score matched study. PLoS One 2020 Jul 6;15(7):e0235207. doi: 10.1371/journal.pone.0235207.

9. Madelaire C, Gustafsson F, Kristensen SL, şi colab. Burden and Causes of Hospital Admissions in Heart Failure During the Last Year of Life. JACC Heart Fail 2019 Jul;7(7):561-570. doi: 10.1016/j.jchf.2019.03.018.

10. Yamazaki D, Hitomi H, Nishiyama A. Hypertension with diabetes mellitus complications. Hypertens Res 2018 Mar;41(3):147-156. doi: 10.1038/s41440-017-0008-y.

11. Bakris GL, Williams M, Dworkin L, şi colab. Preserving renal function in adults with hypertension and diabetes: a consensus approach. National Kidney Foundation Hypertension and Diabetes Executive Committees Working Group. Am J Kidney Dis 2000 Sep;36(3):646-61. doi: 10.1053/ajkd.2000.16225.

12. Wang YR, Alexander GC, Stafford RS. Outpatient hypertension treatment, treatment intensification, and control in Western Europe and the United States. Arch Intern Med 2007 Jan 22;167(2):141-7. doi: 10.1001/archinte.167.2.141. Erratum in: Arch Intern Med 2007 Apr 9;167(7):648.

13. Jones JK, Gorkin L, Lian JF, şi colab. Discontinuation of and changes in treatment after start of new courses of antihypertensive drugs: a study of a United Kingdom population. BMJ 1995 Jul 29;311(7000):293-5. doi: 10.1136/bmj.311.7000.293.

14. Gupta P, Patel $P$, Štrauch $B$, şi colab. Biochemical Screening for Nonadherence Is Associated With Blood Pressure Reduction and Improvement in Adherence. Hypertension 2017 Nov;70(5):1042-1048. doi: 10.1161/HYPERTENSIONAHA.117.09631. 